\title{
Editorial
}

\section{Rio+20: a critique - The global is personal: the personal is global}

Following two decades on from the ground-breaking United Nations Conference on the Human Environment in Stockholm in 1972, the United Nations Conference on Environment and Development in Rio in 1992 promised much in terms of the maturing of international environmental law. Among its most significant achievements, which included reaching international agreements on climate change and biodiversity, was the launch of the supposedly paradigm shifting concept of sustainable development into international law and policy agendas and ultimately, our global consciousness. This development ostensibly represented an attempt to redraw the relationship between humanity and the environment on a more viable footing, recognizing the complex interplay between environmental, social and economic factors. Accordingly, the United Nations Conference on Sustainable Development (Rio+20) provided an ideal opportunity to take stock of progress - or the lack of it - in the intervening 20 years. What then was made of this opportunity?

In fairness, as Adelman suggests, there is much to be discouraged about both in relation to the Rio+20 process and its outcomes. Widespread disappointment is clearly indicated not only by the (arguably expected) critical views of the 'usual suspects' (such as Greenpeace, which called Rio+20 a 'failure of epic proportions' ${ }^{1}$ ) but is also evident in the more constrained views of 'establishment' figures. For example, Janez Potočnik (Europe's Environment Commissioner) expressed a certain amount of frustration with the final text, commenting that: ' $[\mathrm{t}]$ he document does not entirely match our ambition or meet the challenge the world faces. But it's an important step forward ... That's why we must engage with it ...'. ${ }^{2}$ Such muted frustration, however, casts off establishment constraints in the views of the more radically inclined nations, whose frustration was communicated in far stronger terms. For example, Nicaragua's representative, Miguel d'Escoto Brockmann, pulled no punches when he stated that '[o]ur final document is an opportunity that has been missed. It contributes almost nothing to our struggle to survive as a species ....? ${ }^{3}$

The depressing reality is that in the context of the stagnation that has characterized the more challenging aspects of international environmental law in recent years (characterized - as Lyster points out - most markedly by the recurrent failure of the Climate Change regime to make meaningful progress in developing a successor to the Kyoto Protocol), the very fact that any agreement was reached at all at Rio+20 is significant - even if that significance is painfully paradoxical in its implications.

1. J Watts and L Ford, 'Rio+20 Earth Summit: Campaigners Decry Final Document', <http://www.guardian.co.uk/environment/2012/jun/23/rio-20-earth-summit-document> accessed 8 October 2012.

2. Ibid.

3. Ibid. 
The summit's outcome document, 'The Future We Want' ${ }^{4}$ for example, commits to initiatives such as developing 'Sustainable Development Goals' and to augmenting the position of the UN Environment Programme, yet - taken as a whole - merely represents a 'holding position' on sustainability. The Rio+20 outcome document largely reiterates past commitments (most of which have yet to be adequately addressed even two decades after they were made). It also fails to address issues glossed over at the 1992 Earth Summit and which remain fundamental to progressing the paradigm shift required by the depth of the challenges now facing the global community: notably the North/South divide; the relationship between environment and development; and most fundamentally, how (and indeed if) the social/economic/environmental troika as expressed in the Rio Declaration and Agenda 21 can be effectively operationalized.

The articles in this edition seek to address a number of outstanding concerns relevant to Rio+20's paradoxical significance/failure. It is notable that all of them, albeit in a variety of ways, argue that our approach to both sustainability issues in general, and in its specific manifestations in more or less discrete areas of environmental crisis, suffers both in theory and practice from limitations reflecting the relatively impermeable and exclusionary processes of international law and policy dialogue. These processes remain dominated by States whose entrenched positions seem to have brought us to what amounts in practical - if not in absolute - terms to an impasse generated by a failure of imagination. One result of this failure is that, despite ever clearer messages from science about the pressing nature of our plight, the development (or rather lack of development) of international law and policy in this area is revealing itself to be singularly lacking in an ethically responsible level of urgency. This relative inaction looks increasingly likely to threaten our survival as a species as crucial planetary boundaries ${ }^{5}$ are approached and breached.

Adelman, in his contribution to this edition, 'Rio+20: sustainable injustice in a time of crises', argues that the failures in the Rio+20 process can be laid at the door of its replication of the original failures of sustainable development discourse in the new guise of the 'green economy' initiative forming one of Rio+20's main themes. He points to the perpetuation of embedded injustices inflicted upon the world's poor by the failure of the international community to respond in a mature fashion to the interlinking crises of sustainability as expressed in the global economic crash, climate change and food insecurity. Adelman argues that this systemic failure is rooted in the Euro-centric international system's insistence on according totemic significance to the role of the market in tackling environmental problems - an approach that utterly fails to engage with the credibility gap emerging in the part-erosion of neoliberalism and the epistemological crisis that the interlinked material crises facing us entails. Adelman points out that such crisis necessitates fostering a new creativity in epistemological endeavour. Drawing on counter-hegemonic thinking, notably

4. Resolution adopted by the General Assembly 66/288 'The Future We Want', <http:// daccess-dds-ny.un.org/doc/UNDOC/GEN/N11/476/10/PDF/N1147610.pdf?OpenElement> accessed 8 October 2012.

5. J Rockström, W Steffen, K Noone, Å Persson, FS Chapin III, E Lambin, TM Lenton, M Scheffer, C Folke, H Schellnhuber, B Nykvist, CA De Wit, T Hughes, S van der Leeuw, H Rodhe, S Sörlin, PK Snyder, R Costanza, U Svedin, M Falkenmark, L Karlberg, RW Corell, VJ Fabry, J Hansen, B Walker, D Liverman, K Richardson, P Crutzen and J Foley, 'Planetary Boundaries: Exploring the Safe Operating Space for Humanity' (2009) 14(2) Ecology and Society $32<$ http://www.ecologyandsociety.org/vol14/iss2/art32/> accessed 8 October 2012. 
Mignolo's work on coloniality and de Sousa Santos's call for the development of an 'ecology of knowledges' approach to sustainability, Adelman invokes emerging radical and indigenous-thought rooted South American conceptions of what may be broadly termed an Earth jurisprudence as offering the route through which to address the injustices that he views as having been perpetuated in the Rio+20 process and in 'The Future We Want'.

Lyster, in her contribution to this edition, 'Towards a global justice vision for climate law in a time of "unreason", places the on-going unsustainable praxis of global climate change law and policy (viewed as being a 'key disrupter' of sustainable development in 'The Future We Want') under stern scrutiny. She points to the cognitive dissonance produced by the growing weight of scientific evidence on climate change on the one hand and by retarded international law and policy responses to the imperatives that it raises on the other. She terms this problem 'unreason' and regards addressing it as one of the great challenges we face. Lyster, in common with Adelman, suggests that meaningful engagement with the climate change agenda requires broadening the range of active participants in the debate, specifically to counter the impasse generated by State-centric self-interest by adopting a much broader participative approach based on a vision of global justice. Such an approach incorporates the vulnerability of those already bearing the brunt of the first harbingers of climate change crisis and brings home the responsibility for it to the here and now, rather than allowing it to be conveniently off-loaded onto future generations. In an approach that offers a stimulating counter-position to Posner and Weisbach's climate change justice methodology, Lyster fashions her global justice argument by drawing on the philosophical resources offered by Sen's conception of international justice and by Gardiner's work on the moral implications of the climate change debate. To this end, Lyster suggests rejecting fashionable distributive and corrective approaches to climate justice as inadequate responses to the issues. Instead, she argues, it is imperative that an 'impartial public reasoning' process, based on practical reason and free from the influence of both parochialism and overweening vested interests, is developed in short order as both an antidote to the dangers of 'unreason' and in order to facilitate the adoption of a global justice approach to climate change.

Gianolla, in his article 'Human rights and nature: intercultural perspectives and international aspirations', considers the multifarious ways in which the powerful and persuasive human rights agenda may have proved detrimental to the environment. Gianolla critiques the anthropocentrism of mainstream human rights and draws comparisons with more holistic and less materialistic indigenous/inter-cultural conceptions of human rights in order to investigate whether the latter offer a more sustainable pathway for articulating the human/nature relationship. Looking to these holistic and integrative cosmologies, where both humanity and nature are viewed as having intrinsic value and are seen as being inherently interdependent, Gianolla discusses more fully the innovative approaches to nature's rights and resultant novel legal provisions emerging in Bolivia and Ecuador. He sees these examples as offering a potential corrective to the dominant anthropocentrism of mainstream human rights - bringing western and non-western conceptions of human rights together in a vision of 'environmental justice' capable of bridging the distance between them. Gianolla draws on insights emerging from indigenous epistemologies in order to fashion an intertwined vision of humanity and nature in the form of a 'living commons' approach which embraces them both. This approach goes far beyond the notion of 'the common inheritance of Humanity' by invoking a much more expansive notion of planetary welfare, promoting the indigenous concept of buen 
vivir or 'good life'. Gianolla's frame of understanding adopts a much wider view of rights than do traditional human rights models, viewing nature in and of 'herself' (Gianolla's chosen term of reference), as being a viable rights holder as a living 'being'. To give both form and substance to this conception, Gianolla's thinking, in common with that of the other contributors to this edition, promotes the adoption of a more broadly based, in this case specifically inter-cultural and indigenous peoples and nature inclusive, approach to re-orienting the rights debate on a more sustainable basis.

Collins's contribution to this edition, 'Security of the person, peace of mind: a precautionary approach to environmental uncertainty', takes the rights debate from Gianolla's macro-level focus to a micro-level analysis examining security of the person in the specific context of risk. Collins contrasts the relatively recent advent of the precautionary approach in international law in the Rio Declaration of 1992 with the long established concept of security of the person rooted in the Universal Declaration of Human Rights. She traces the development of the precautionary approach in tandem with risk based claims in cases of scientific uncertainty, considering the potential for human rights arguments based on the violation of security of the person. Collins argues persuasively that the precautionary approach and the security of the person are in fact inextricably linked, as environmental degradation is inimical to (both the psychological and physical) security of the person and precaution is one of the tools available to deal with it in cases where risk is at issue. In so doing, Collins adopts an expansive and holistic approach to human rights, regarding the psychological element of harm and the nature of continuing environmental anxiety as being as integral to security of the person as is its physical component. She considers, like Lyster, the need for the law to engage with the lived experience of affected communities in order to foster a just approach. Accordingly, Collins specifically considers the important recent litigation by the Aamjiwnaang indigenous people in Sarnia, Canada in raising 'environmental peace of mind' as the basis of a legal claim founded on security of the person. She points to the way in which uncertainty is treated in prevailing environmental regulation and the resultant problems that this poses to claimants in litigation, arguing that the way in which the law currently engages with these issues can be inimical to protecting both the claimants' rights and to protecting the environment.

The Rio+20 process and 'The Future We Want' outcome document - at worst illustrate a lamentable failure of imagination in the international community concerning the urgency of tackling the escalating and interlinked myriad environmental and existential challenges that we face. At best, Rio+20 stands as testimony to how far we still have to go in assimilating the profound paradigm shift mandated by our current situation: a vision of sustainability grounded in an understanding of the staggering implications of rapidly approaching key planetary boundaries is now fundamentally non-negotiable - not only to ensure 'development', but to ensure the continuing survival of human (and other forms of) life itself. Thus far our international institutions are barely 'talking the talk', let alone 'walking the walk', that this would require though to be fair, in this they may be reflecting our own unwillingness/inability to countenance the challenges and the profound alterations in our expectations and lifestyles that fully engaging with the imperatives of sustainability will ultimately require. Nonetheless, there are creative alternatives that we can explore in responding to key sustainability issues, such as Adleman's application of 'the ecology of knowledge's approach and Lyster's 'impartial public reasoning' approach in the climate change arena. Gianolla draws us into equally radical territory in reconsidering the shape of the human/nature relationship through a 'living commons' approach encapsulating 
humanity and (the rest of) nature as living beings fully worthy of protection and respect. This type of imaginative debate and the reconstruction of some of our fundamental ideas and approaches can ultimately bear fruit. We can see signs of this, even in the Rio+20 process and outcome, demonstrating the emergence of Earth jurisprudence/ Pachamama approaches on the global stage. Such developments indicate that we may be beginning to at least open up to the idea that we need to develop radical new ways of thinking about the human/environment relationship. We can but hope that developments of this nature, accommodating new voices and fresh perspectives, will reinvigorate an area of international endeavour in very real danger of becoming moribund - after all, our continued flourishing and that of the biosphere of which we form but a part - and upon which we ultimately rely - depends on it.

Karen Morrow (Co-Editor in Chief) Centre for Environment and Energy Law and Policy, Swansea University, UK 